\title{
PELAKSANAAN DIVERSI DALAM PENYELESAIAN TINDAK PIDANA PENCURIAN YANG DILAKUKAN OLEH ANAK SEBAGAI BENTUK PENDEKATAN RESTORATIVE JUSTICE (Studi di Wilayah Hukum Kepolisi an Resort Banjarnegara) Oleh : Triadi Agus Purwanto ${ }^{85}$
}

\begin{abstract}
This thesis is motivated by the problem of Children who are the assets of the nation, as part of the young generation of children plays a very strategic role as a successor of a nation. Therefore, the state must provide protection for children if the child becomes a criminal offender. One of the solutions that can be taken in handling the case of crime of theft committed by the Child is through Restorative Justice approach, which is implemented by diversion as regulated in Law Number 11 Year 2012 on Child Criminal Justice System. Banjarnegara Resort Police has implemented a version for handling of criminal cases of theft committed by the Child as an effort to settle the case. Based on this, the issue raised in this thesis is how the implementation of the diversion in the settlement of criminal acts of theft committed by the Children in the Legal District of Banjarnegara Police as a form of Restorative Justice approach and constraints in the implementation of such diversions.

This thesis research method uses Juridical Sociological method which observes how the reaction and interaction that occurs when the norm system works in society. The data analysis used in this research is qualitative data analysis method, that is research which produce descriptive-analysis data.

Based on the results of research and discussion that has been done by the author, it can be concluded that the Implementation of Diversity for Children who committed criminal acts in the district of Polres Banjarnegara conducted by Investigator Satreskrim Unit Women and Children Services Polres Banjarnegara already in accordance with the provisions of Article 7 paragraph (2) Law Number 11 Year 2012 on the Child Criminal Justice System. Implementation Diversi done with several stages of the preparation stage diversi, stage of deliberation and stage of diversion results. Obstacles in the implementation of diversified by the investigator Satreskrim Unit Women and Children Services Polres Banjarnegara because of the legal substance factor that is not yet the implementation of the Act No. 11 of 2012 on the Criminal Justice System of Children, especially about the diversion, the absence of SOP for the police about the diversion and factors of legal culture that is still lack of understanding about the importance of society Diversi and still there is suspicion of some residents to the implementation of diversity.

Keywords: Approach, Child, Retroactive justice
\end{abstract}

\section{ABSTRAK}

Tesis ini dilatarbelakangi oleh permasalahan yaitu Anak yang merupakan aset bangsa, sebagai bagian dari generasi muda anak berperan sangat strategis sebagai successor suatu bangsa, Oleh karenanya, negara harus memberikan perlindungan terhadap anak apabila anak tersebut menjadi pelaku tindak pidana. Salah satu solusi yang dapat ditempuh dalam penanganan perkara tindak pidana pencurian yang dilakukan oleh Anak adalah melalui pendekatan Restorative Justice, yang dilaksanakan dengan cara pengalihan (diversi) sebagaimana yang diatur dalam Undang-undang Nomor 11 Tahun 2012 tentang Sistem Peradilan Pidana Anak. Kepolisian Resort Banjarnegara telah menerapkan diversi bagi penanganan perkara tindak pidana

${ }^{85}$ Pengadilan Negeri Jember, HP. 081328727347 
pencurian yang dilakukan oleh Anak sebagai upaya penyelesaian perkara tersebut. Berdasarkan hal tersebut, permasalahan yang diangkat dalam tesis ini adalah bagaimana pelaksanaan diversi dalam penyelesaian penanganan tindak pidana pencurian yang dilakukan oleh Anak di Wilayah Hukum Polres Banjarnegara sebagai bentuk pendekatan Restorative Justice serta kendala dalam pelaksanaan diversi tersebut.

Metode penelitian tesis ini menggunakan metode Yuridis Sosiologis yang mengamati bagaimana reaksi dan interaksi yang terjadi ketika sistem norma itu bekerja di dalam masyarakat. Analisis data yang dipergunakan dalam penelitian ini adalah metode analisis data kualitatif, yaitu penelitian yang menghasilkan data deskriptif-analisis.

Berdasarkan hasil penelitian dan pembahasan yang telah dilakukan oleh penulis, maka dapat diambil simpulan bahwa Pelaksanaan Diversi bagi Anak yang melakukan tindak pidana di wilayah hukum Polres Banjarnegara yang dilakukan oleh Penyidik Satreskrim Unit Pelayanan Perempuan dan Anak Polres Banjarnegara telah sesuai dengan ketentuan Pasal 7 ayat (2) Undang-Undang Nomor 11 Tahun 2012 Tentang Sistem Peradilan Pidana Anak. Pelaksanaan Diversi dilakukan dengan beberapa tahap yaitu tahap persiapan diversi, tahap musyawarah dan tahap hasil diversi. Hambatanhambatan dalam pelaksanaan diversi oleh penyidik Satreskrim Unit Pelayanan Perempuan dan Anak Polres Banjarnegara karena faktor subtansi hukum yaitu belum adanya peraturan pelaksanaan dari Undang-Undang Nomor 11 tahun 2012 tentang Sistem Peradilan Pidana Anak terutama mengenai diversi, belum adanya SOP bagi kepolisian mengenai diversi dan faktor budaya hukum yaitu masih kurangnya pemahaman masyarakat tentang arti pentingnya Diversi serta masih adanya kecurigaan dari sebagian warga terhadap pelaksanaan Diversi.

Kata Kunci: pendekatan, anak, pengadilan yang menguatkan

\section{A. Pendahuluan}

Anak adalah bagian yang tak terpisahkan dari keberlangsungan hidup manusia dan keberlangsungan sebuah bangsa dan negara. Dalam konstitusi Indonesia, anak memiliki peran strategis yang secara tegas dinyatakan bahwa negara menjamin hak setiap anak atas kelangsungan hidup, tumbuh dan berkembang, serta atas perlindungan dari kekerasan dan diskriminasi. Oleh karena itu, kepentingan terbaik bagi anak patut dihayati sebagai kepentingan terbaik bagi kelangsungan hidup berbangsa dan bernegara. Setiap anak mempunyai harkat dan martabat yang patut dijunjung tinggi dan setiap anak harus mendapatkan hak-haknya tanpa anak tersebut meminta. Hak-hak anak tersebut sebagaimana ketentuan Konvensi Hak Anak (Convention on The Right of Child) yang diratifikasi oleh pemerintah Indonesia melalui Keputusan Presiden Nomor 36 Tahun 1990 kemudian juga dituangkan dalam Undang-Undang Nomor 4 Tahun 1979tentang Kesejahteraan Anak dan Undang-undang Nomor 23 Tahun 2002 tetnag Perlindungan Anak yang mengemukakan prinsip-prinsip umum tentang perlindungan anak yang diantaranya yaitu non diskriminasi, kepentingan terbaik bagi anak, kelangsungan hidup dan tumbuh kembang anak dan menghargai partisipasi anak. 
Anak merupakan aset bangsa, sebagai bagian dari generasi muda anak berperan sangat strategis sebagai successor suatu bangsa. Dalam konteks Indonesia, anak adalah penerus cita-cita perjuangan suatu bangsa. Selain itu, anak merupakan harapan orang tua, harapan bangsa dan negara yang akan melanjutkan tongkat estafet pembangunan serta memiliki peran strategis, mempunyai ciri atau sifat khusus yang akan menjamin kelangsungan eksistensi bangsa dan negara pada masa depan. Oleh karena itu, setiap anak harus mendapatkan pembinaan sejak dini, anak perlu mendapat kesempatan yang seluasluasnya untuk dapat tumbuh dan berkembang secara optimal, baik fisik, mental maupun sosial. Terlebih lagi bahwa masa kanak-kanak merupakan periode pembentukan watak, kepribadian dan karakter diri seorang manusia, agar kehidupan mereka memiliki kekuatan dan kemampuan serta berdiri tegar dalam meniti kehidupan. ${ }^{86}$

Dalam periode perkembangannya, anak gampang terpengaruh oleh berbagai macam tindakan yang menimbulkan kerugian mental, fisik, sosial dalam berbagai bidang kehidupan dan penghidupan, dan dari berbagai pengaruh sistem yang

${ }^{86}$ Maidin Gultom, Perlindungan Hukum Terhadap Anak dalam Sistem Peradilan Pidana Anak di Indonesia, Bandung, Refika Aditama, 2008, hal. 1. ada. Pada hakikatnya anak tidak dapat melindungi diri sendiri dari berbagai macam tindakan tersebut, oleh karena itu anak harus dibantu oleh orang lain dalam melindungi dirinya, mengingat situasi dan kondisinya. Oleh karenanya, negara harus memberikan perlindungan terhadap anak apabila anak tersebut menjadi pelaku tindak pidana. Perlindungan anak ini dapat dilakukan dari segala aspek, mulai pada pembinaan pada keluarga, kontrol sosial terhadap pergaulan anak, dan penanganan yang tepat melalui peraturan-peraturan yang baik yang dibuat oleh sebuah negara.

Anak yang melakukan pelanggaran hukum atau melakukan tindakan kriminal sangat dipengaruhi beberapa faktor lain di luar diri anak seperti pergaulan, pendidikan, teman bermain dan sebagainya, karena tindak pidana yang dilakukan oleh anak pada umumnya adalah merupakan proses meniru ataupun terpengaruh tindakan negatif dari orang dewasa atau orang disekitarnya. Anak sebagai Pelaku tindak pidana dalam hal ini bisa dikategorikan sebagai anak yang berkonflik dengan hukum Dalam ketentuan Umum Undang-undang Nomor 11 Tahun 2012 tentang Sistem Peradilan Pidana Anak Pasal 1 angka 3 memberikan definsi anak yang berkonflik dengan hukum yaitu anak yang telah berumur 12 (dua belas) tahun tetapi belum berumur 18 (delapan 
1083 | Jurnal Idea Hukum

Vol. 4 No. 2 Oktober 2018

Magister Hukum Fakultas Hukum Universitas Jenderal Soedirman

belas) tahun yang diduga melakukan tindak pidana.

Penanggulangan kejahatan tidak hanya dilakukan dengan hukum pidana, akan tetapi bisa juga dengan usahausaha lain tanpa menggunakan hukum pidana. Usaha yang terakhir ini biasanya memang tidak secara langsung dimaksudkan untuk mernanggulangi kejahatan, akan tetapi efeknya untuk menjauhkan orang dari kejahatan pada umumnya tidak diragukan, yang dimaksudkan ialah misalnya pendidikan agama, pendidikan jiwa, pengisian waktu terluang dengan kegiatan pramuka dan sebagainya. ${ }^{87}$

Ketika anak tersebut diduga melakukan tindak pidana, sistem peradilan formal yang ada pada akhirnya menempatkan anak dalam status narapidana tentunya membawa konsekuensi yang cukup besar dalam hal tumbuh kembang anak. Proses penghukuman yang diberikan kepada anak lewat sistem peradilan pidana formal dengan memasukkan anak ke dalam penjara ternyata tidak berhasil menjadikan anak jera dan menjadi pribadi yang lebih baik untuk menunjang proses tumbuh kembangnya. Penjara justru seringkali membuat anak semakin profesional dalam melakukan tindak kejahatan. Untuk melakukan perlindungan terhadap anak dari

87 Sudarto, Kapita Selekta Hukum Pidana, Cetakan ke-3, PT Alumni, Bandung, 2006, hal.43. pengaruh proses formal sistem peradilan pidana, maka timbul pemikiran manusia atau para ahli hukum dan kemanusiaan untuk membuat aturan formal tindakan mengeluarkan seorang anak yang melakukan pelanggaran hukum atau melakukan tindak pidana dari proses peradilan pidana dengan memberikan alternatif lain yang dianggap lebih baik untuk anak. Negara Republik Indonesia telah meratifikasi Konvensi Hak Anak melalui Keppres No.36 Tahun 1990 tentang pengesahan Convention on The Right of Child (Konvensi tentang hak-hak anak). Peratifikasian ini sebagai upaya negara untuk memberikan perlindungan terhadap anak. Dari berbagai isu yang ada dalam konvensi hak anak salah satunya yang sangat membutuhkan perhatian khusus adalah anak, diantaranya anak yang berkonflik dengan hukum. Salah satu solusi yang dapat ditempuh dalam penanganan perkara tindak pidana anak adalah pendekatan Restorative Justice, yang dilaksanakan dengan cara pengalihan (diversi). Restorative Justice merupakan proses penyelesaian yang dilakukan di luar sistem peradilan pidana dengan melibatkan korban, pelaku, keluarga korban dan pelaku, masyarakat serta pihak-pihak yang berkepentingan dengan suatu tindak pidana yang terjadi untuk mencapai kesepakatan dan penyelesaian. 
Berdasar ketentuan Umum Pasal 1 angka 6 Undang-undang Nomor 11 Tahun 2012 tentang Sistem Peradilan Pidana Anak menyatakan bahwa Keadilan Restoratif adalah penyelesaian perkara tindak pidana dengan melibatkan pelaku, korban, keluarga pelaku/korban, dan pihak lain yang terkait untuk bersama-sama mencari penyelesaian yang adil dengan menekankan pemulihan kembali pada keadaan semula dan bukan pembalasan. Hal tersebut kembali ditegaskan dalam ketentuan Pasal 5 ayat (1) yang menyebutkan bahwa Sistem Peradilan Pidana Anak wajib mengutamakan pendekatan Keadilan Restoratif.

Kata diversi berasal dari bahasa Inggris Diversion yang berarti Pengalihan". Berdasarkan Pedoman Umum Bahasa Indonesia Yang Disempurnakan dan Pedoman Umum Pembentukan Istilah disesuaikan dalam bahasa Indonesia menjadi Diversi. ${ }^{88}$ Menurut Romli Artasasmita dalam Setya Wahyudi, Diversi yaitu kemungkinan Hakim menghentikan atau mengalihkan/tidak meneruskan pemeriksaan perkara dan pemeriksaan terhadap anak selama proses pemeriksaan di muka sidang. ${ }^{89}$

\footnotetext{
${ }^{88}$ Setya Wahyudi, 2011, Implementasi Ide Diversi Dalam Pembaruan Sistem Pidana Anak Di Indonesia, Genta Publishing, Yogyakarta, hal. 14 89 Ibid., hal. 15
}

Dalam Pasal 1 angka 7 Undangundang Nomor 11 Tahun 2012 tentang Sistem Peradilan Pidana Anak disebutkan Diversi adalah pengalihan penyelesaian perkara anak dari proses peradilan pidana ke proses di luar peradilan pidana. Undang-undang Nomor 11 Tahun 2012 tentang Sistem Peradilan Pidana Anak telah mengatur tentang Diversi yang berfungsi agar anak yang berhadapan dengan hukum tidak terstigmatisasi akibat proses peradilan yang harus dijalaninya. Penggunaan mekanisme diversi tersebut diberikan kepada para penegak hukum dalam menangani pelanggarpelanggar hukum yang melibatkan anak tanpa menggunakan pengadilan formal. Penerapan diversi tersebut dimaksudkan untuk mengurangi dampak negatif keterlibatan anak dalam suatu proses peradilan.

Tujuan Diversi sebagaimana disebutkan dalam Pasal 6 Undangundang Nomor 11 Tahun 2012 tentang Sistem Peradilan Pidana Anak yaitu :

a. Mencapai perdamaian antara korban dan Anak;

b. Menyelesaikan perkara Anak di luar proses peradilan;

c. Menghindarkan Anak dari perampasan kemerdekaan;

d. Mendorong masyarakat untuk berpartisipasi; dan

e. Menanamkan rasa tanggung jawab kepada Anak.

Makin meningkatnya jumlah pelanggaran hukum yang melibatkan anak menyebabkan makin meningkatnya jumlah anak yang 
1085 | Jurnal Idea Hukum

Vol. 4 No. 2 Oktober 2018

Magister Hukum Fakultas Hukum Universitas Jenderal Soedirman

berhadapan dengan hukum, dimana salah satunya adalah tindak pidana pencurian yang dilakukan oleh anak. Tindak pidana pencurian yang dilakukan oleh anak seringkali bukan berasal dari faktor pribadi anak tersebut, namun juga sangat dipengaruhi faktor-faktor lain di luar diri anak seperti pergaulan, pendidikan, teman bermain dan sebagainya, karena tindak pidana yang dilakukan oleh anak pada umumnya adalah merupakan proses meniru ataupun terpengaruh tindakan negatif dari orang dewasa atau orang disekitarnya.

Di wilayah hukum Kepolisian Resort Banjarnegara, jumlah tindak pidana pencurian yang dilakukan oleh anak sejak tahun 2014 sampai dengan 2015 berjumlah 6 (enam) perkara dan dari 6 (enam) perkara tersebut yang sampai tahap pelimpahan dan putusan dari Pengadilan Negeri Banjarnegara berjumlah 5 (lima) perkara. Dari 4 (lima) perkara yang disidangkan oleh Pengadilan Negeri Banjarnegara tersebut putusannya adalah dalam bentuk pemidanaan. Hal ini apabila dihubungkan dengan Undang-undang Nomor 11 tahun 2012 tentang Sistem Peradilan Pidana Anak terdapat kesenjangan, dimana dalam Undangundang Nomor 11 tahun 2012 tentang Sistem Peradilan Pidana Anak disebutkan dalam penyelesaian tindak pidana yang dilakukan oleh anak mengedepankan prinsip diversi.
Di wilayah hukum Kepolisian Resort Banjarnegara telah ada 1 (satu) penyelesaian perkara yang melibatkan anak sebagai pelaku tindak pidana pencurian yang dilakukan dengan menerapkan Restorative Justice dengan proses diversi. Dalam prosesnya perkara tersebut telah dilakukan penyelesaian di luar proses peradilan pidana dengan penerapan Restorative Justice dengan menerapkan diversi pada tingkat pemeriksaan di Kepolisian Resort Banjarnegara walaupun ada juga perkara yang sampai tahap pelimpahan dan putusan dari Pengadilan Negeri Banjarnegara. Hal tersebut tentunya kembali kepada kualitas Kepolisian Resort Banjarnegara dalam menerapkan diversi bagi anak yang melakukan tindak pidana dan kemauan dari pihak anak dan korban dalam menerapkan diversi sebagai upaya penyelaian perkara tersebut.

\section{B. Rumusan Masalah}

Berdasarkan uraian yang telah dikemukakan pada latar belakang di atas, maka dapat dirumuskan permasalahan sebagai berikut:

1. Bagaimana pelaksanaan diversi dalam penyelesaian penanganan tindak pidana pencurian yang dilakukan oleh anak di Wilayah Hukum Polres Banjarnegara?

2. Apakah yang menjadi kendala pelaksanaan diversi dalam 
penyelesaian penanganan tindak pidana pencurian yang dilakukan oleh anak di Wilayah Hukum Polres Banjarnegara?

\section{Metode Penelitian}

Metode penelitian yang dipergunakan adalah Yuridis Sosiologis. Sumber Data adalah Data Primer dan Data Sekunder, dengan analisis data yang dipergunakan dalam penelitian ini adalah metode kualitatif.

\section{Hasil Penelitian Dan}

\section{Pembahasan}

1. Proses Pelaksanaan Diversi Terhadap Tindak Pidana Pencurian Yang Dilakukan Oleh Anak Oleh Penyidik Satreskrim Unit Pelayanan Perempuan dan Anak Polres Banjarnegara.

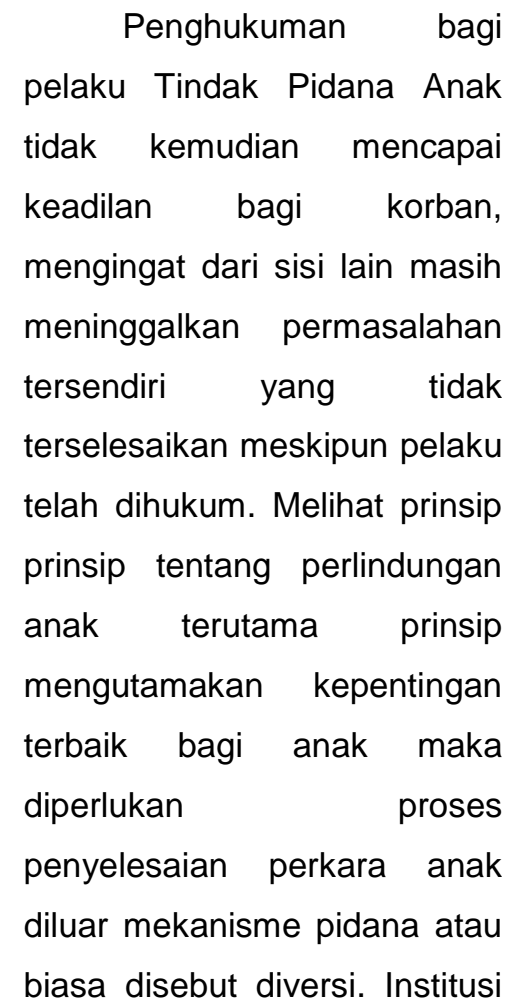

penghukuman bukanlah jalan untuk menyelesaikan permasalahan anak karena justru di dalamnya rawan terjadi pelanggaranpelanggaran terhadap hak anak.

Berdasarkan hal tersebut dibutuhkan suatu acara dan prosedur di dalam sistem yang dapat mengakomodasi penyelesaian perkara yang salah satunya adalah dengan menggunakan pendekatan keadilan restoratif, melalui suatu pembaharuan hukum yang tidak sekedar mengubah undang-undang semata tetapi juga memodfikasi sistem peradilan pidana yang ada, sehingga semua tujuan yang di kehendaki oleh hukumpun tercapai. Salah satu bentuk mekanisme restoratif justice tersebut adalah dialog yang dikalangan masyarakat Indonesia lebih dikenal dengan sebutan "musyawarah untuk mufakat”. Sehingga diversi khususnya melalui konsep restoratif justice menjadi suatu pertimbangan yang sangat penting dalam menyelesaikan perkara pidana yang dilakukan oleh anak. 
1087 | Jurnal Idea Hukum

Vol. 4 No. 2 Oktober 2018

Magister Hukum Fakultas Hukum Universitas Jenderal Soedirman

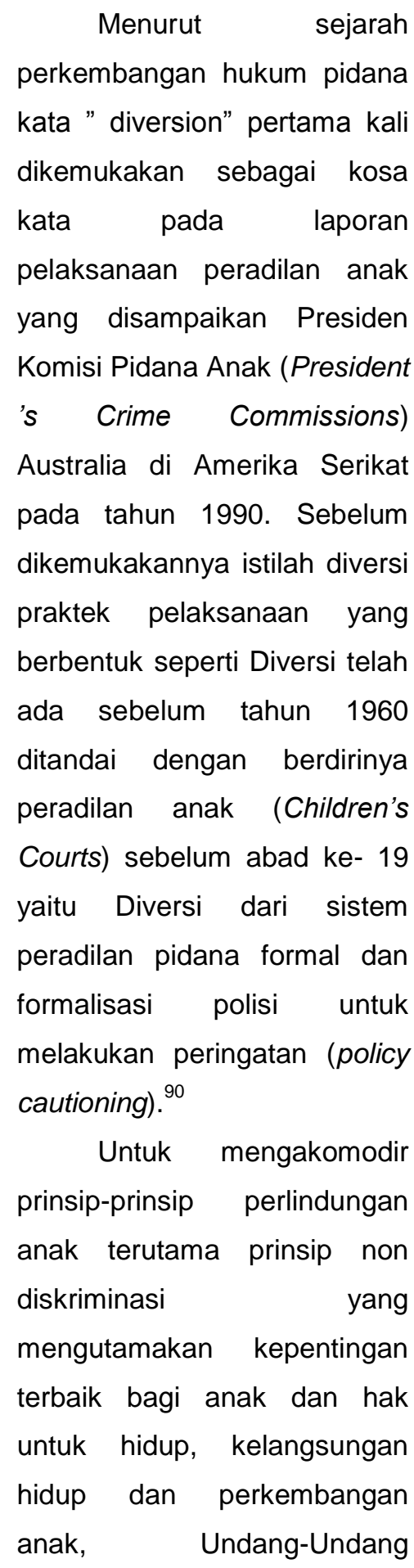

Republik Indonesia Nomor 11

${ }^{90}$ Marlina, 2008, Penerapan Konsep Diversi Terhadap Anak Pelaku Tindak Pidana dalam Sistem Peradilan Pidana Anak, Jurnal Equality, Jakarta, hal. 1.
Tahun 2012 tentang Sistem

Peradilan Pidana Anak

(selanjutnya disingkat UU SPPA) yang merupakan pergantian terhadap Undangundang Nomor 3 Tahun 1997 tentang Pengadilan Anak telah mengatur secara tegas mengenai Keadilan Restoratif dan Diversi yang dimaksudkan untuk menghindari dan menjauhkan anak dari proses peradilan sehingga dapat menghindari stigma terhadap anak yang berhadapan dengan hukum dan si anak dapat kembali ke dalam lingkungan sosial secara wajar. Oleh karena itu sangat diperlukan peran serta semua pihak dalam mewujudkan hal tersebut.

Menurut Natangsa Subakti, dalam proses perkara pidana fungsionaris penegakan hukum, yaitu Penasehat Hukum, Polisi, Jaksa dan Hakim cenderung bekerja secara terpola dengan memfokuskan perhatian pada perbuatan yang dilarang atau tindak pidana (crime, strafbaarfeit) serta pelaku tindak pidana (criminal, 
offender) namun mengabaikan korban tindak pidana (victim). ${ }^{91}$ Penyelesaian diluar Pengadilan melalui mediasi penal telah diatur dalam Undang-Undang Nomor 11 Tahun 2012 Tentang Sistem Peradilan Pidana Anak. Menurut Pasal 5 ayat (3) Undang-undang Nomor 11 Tahun 2012 tentang Sistem Peradilan Pidana Anak menyatakan bahwa Sistem Peradilan Pidana Anak sebagimana dimaksud dalam ayat (2) huruf a dan b wajib diupayakan Diversi, sedangkan didalam Pasal 7 ayat (2) ditentukan bahwa Diversi wajib diupayakan pada tingkat penyidikan, penuntutan dan pemeriksaan perkara anak pengadilan negeri dilaksanakan dalam hal tindak pidana yang diancam dengan pidana penjara dibawah 7 (tujuh) tahun dan bukan merupakan pengulangan tindak pidana. Adapun dalam Perma Nomor 4 Tahun 2014 Tentang Pedoman

Pelaksanaan Diversi dalam Sistem Peradilan Pidana Anak Pasal 3 menyebutkan bahwa

${ }^{91}$ Natangsa Subakti, 2015, Peradilan Restoratif Dalam Bingkai Empiri, Teori dan Kebijakan, Genta Publising, Yogyakarta, hal 3.
Hakim anak wajib mengupayakan diversi dalam hal anak didakwa melakukan tindak pidana yang diancam dengan pidana penjara dibawah 7 (tujuh) tahun dan didakwa dengan tindak pidana yang diancam dengan pidana penjara 7 (tujuh) tahun atau lebih dalam bentuk surat dakwaan subsidaritas, alternative, kumulatif maupun kombinasi (gabungan).

Berdasarkan hasil penelitian maka diperoleh data mengenai persepsi aparatur kepolisian tentang pengertian Diversi yaitu Diversi adalah proses pengalihan perkara anak yang melakukan tindak pidana yang diselesaikan dari proses peradilan pidana ke proses diluar peradilan pidana, dasarnya Pasal 1 angka 7 Undang-undang Nomor 11 Tahun 2012 Tentang Sistem Peradilan Pidana Anak, penyelesaian perkara diluar pengadilan ini dilakukan dengan musyawarah atau mediasi yang dihadiri para pihak, selanjutnya mengenai jenis dan syarat-syarat perkara yang dapat diterapkan Diversi, berdasarkan Undang-Undang Nomor 11 Tahun 2012 tentang Sistem Peradilan Pidana 


Anak, Diversi tidak dapat
diterapkan untuk semua
perkara, Diversi hanya dapat
diterapkan untuk perkara yang
diancam pidana dibawah 7
(tujuh) tahun dan bukan
merupakan pengulangan
tindak pidana r baik
pidana/perkara pidana yang
serupa maupun perkara
pidana lainnya yang dilakukan
oleh anak-anak, hal tersebut
mendasarkan pada Pasal 7
ayat (2).

Berdasarkan hal

tersebut diatas maka dapat diperoleh suatu gambaran bahwa penyidik Penyidik Satreskrim Unit Pelayanan Perempuan dan Anak Polres Banjarnegara sudah memahami mengenai Diversi yaitu penyelesaian perkara tindak pidana diluar pengadilan atau pengalihan perkara pidana anak dari proses peradilan menjadi proses diluar peradilan (pengadilan). Penyelesaian perkara ini melalui diversi dengan jalan musyarawah atau mediasi. Pemahaman Diversi dari penyidik ini sesuai dengan ketentuan umum yang diatur dalam Undang-Undang Nomor 11 Tahun 2012 Tentang Sistem Peradilan
Pidana Anak Pasal 1 angka 7 yaitu Diversi adalah pengalihan penyelesaian perkara Anak dari proses peradilan pidana ke proses di luar peradilan pidana. Sedangkan mengenai jenis perkara dan syarat-syarat yang dapat dilakukan dengan jalan Diversi yaitu Diversi diterapkan untuk perkara yang diancam pidana dibawah 7 (tujuh) tahun dan bukan merupakan pengulangan tindak pidana baik pidana/perkara pidana yang serupa maupun perkara pidana lainnya yang dilakukan oleh anak-anak.

Penyelesaian perkara tindak pidana pencurian atas nama Tersangka AM, $S$ dan $\mathrm{KH}$ Penyidik Satreskrim Unit Pelayanan Perempuan dan Anak Polres Banjarnegara dalam menyelesaikan perkara tersebut mengggunakan Diversi. Diversi ini dilakukan berpedoman pada UndangUndang Nomor 11 Tahun 2012 Tentang Sistem Peradilan Pidana Anak dan Peraturan Mahkamah Agung Nomor4 Tahun 2014 Tentang Pedoman Diversi dalam Sistem Peradilan Pidana Anak. Walapun dalam Pasal 
15 Undang-Undang Nomor 11

Tahun 2012 Tentang Sistem

Peradilan Pidana Anak secara

jelas ditentukan mengenai

diversi dilaksanakan

berdasarkan Peraturan

Pemerintah, akan tetapi

sampai dengan perkara ini

ada, peraturan pelaksanaan

tentang diversi belum juga di

keluarkan oleh Pemerintah.

Oleh karena itu demi keadilan

dan kemanfaatan dimana

penyelesaikan perkara yang

melibatkan anak demi

kepentingan yang terbaik bagi

anak itu sendiri. Berdasarkan

hasil penelitian yang dilakukan

oleh penulis mengenai dasar

pertimbangan penyidik anak

dalam melaksanakan Diversi

terhadap perkara anak atas

nama $A M, S$ dan $\mathrm{KH}$ yang

bersumber dari wawancara

dengan Penyidik Satreskrim

Unit Pelayanan Perempuan

dan Anak Polres Banjarnegara

didapatkan hasil sebagai

berikut : bahwa perkara tindak

pidana

pencurian

sebagaimana yang dikenakan

kepada AM sebagaimana

diatur dalam Pasal 362 KUHP

merupakan Pasal yang

ancaman pidananya dibawah

7 (tujuh) tahun maka terhadap

perkara

pencurian sebagaimana yang dikenakan kepada AM, dapat diterapkan Diversi dengan berpedoman pada Undang-Undang Nomor 11 Tahun 2012 Tentang Sistem Peradilan Pidana Anak. Dengan demikian, syarat-syarat untuk bisa dilakukan Diversi dalam hal tindak pidana pencurian yang dilakukan diancam dengan pidana penjara di bawah 7 (tujuh) tahun dan bukan merupakan pengulangan tindak pidana.

Apabila perkara pidana Anak dikenakan dakwaan subsidiaritas, alternatif, kumulatif maupun gabungan sebagaimana yang dikenakan kepada $\mathrm{S}$ dan $\mathrm{KH}$ apabila salah satu dakwaan yang dikenakan terhadap Anak terdapat dakwaan yang ancaman pidananya dibawah 7 (tujuh) tahun maka dapat dilakukan proses Diversi berdasarkan Perma Nomor 4 Tahun $2014 \quad$ Tentang Pedoman Pelaksanaan Diversi Dalam Sistem Peradilan Pidana Anak, dalam Pasal 3 Perma tersebut disebutkan Diversi dapat diterapkan pada perkara yang diancam dengan pidana lebih dari 7 (tujuh) tahun asalkan dengan 
1091 | Jurnal Idea Hukum

Vol. 4 No. 2 Oktober 2018

Magister Hukum Fakultas Hukum Universitas Jenderal Soedirman

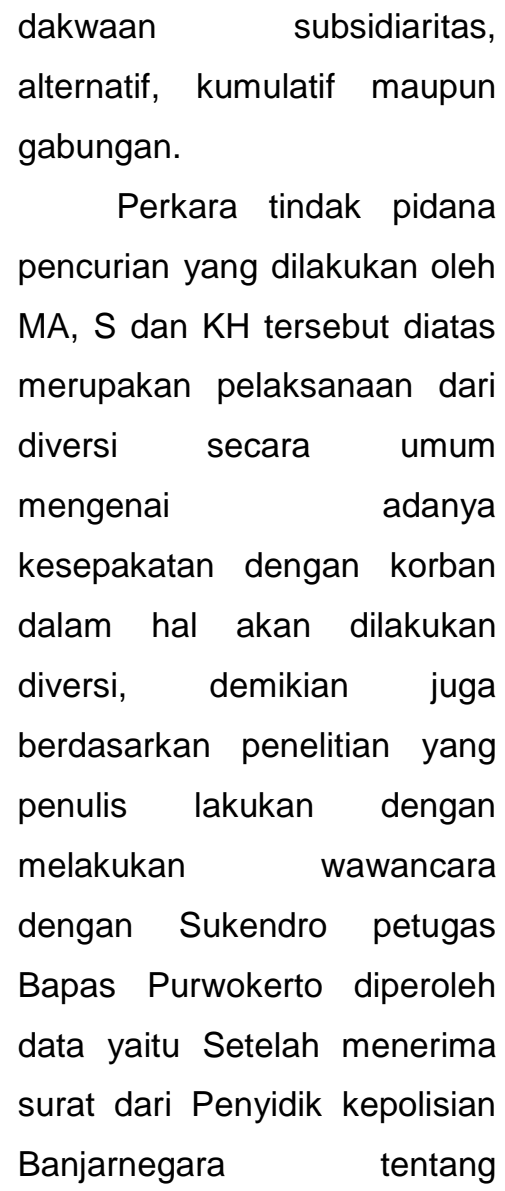
permohonan litmas atas nama AM, Petugas Bapas membuat penelitian kemasyarakatan mengenai perkara atas nama AM dengan memberikan kesimpulan dan saran sebagai berikut:

AM melakukan pencurian karena adanya pengaruh dan ajakan teman yang, adanya pergaulan serta kondisi mental klien yang mudah terpengaruh ajakan omongan temannya untuk mendapatkan uang dengan cara cepat, Bapas Purwokerto merekomendasikan untuk dilakukan Diversi dengan

pendekatan keadilan

restorative untuk kepentingan terbaik bagi anak, sesuai Pasal 14 angka (2) UU RI Nomor 11 Tahun 2012 Tentang Sistem Peradilan Pidana Anak, maka hasil kesepakatan Diversi dikembalikan kepada orang tua sesuai Pasal 10 ayat (2) huruf $c$ dan mendapat bimbingan dari Bapas dengan pertimbangan sebagai berikut:

a. Memperhatikan Pasal 6 dan 7UU SPPA

b. Memperhatikan Pasal 64 ayat (2) huruf $d U U$ No.35 Tahun 2014 tentang perubahan Undang-undang

Nomor 23 Tahun 2002 tentang Perlindungan Anak, maka penjatuhan sanksi yang tepat untuk kepentingan yang terbaik bagi anak.

c. Klien sangat menyesali perbuatannya dan berjanji tidak akan mengulangi perbuatan yang melanggar hukum.

d. Orang tua, masyarakat dan pemerintah masih 
bersedia mengadakan pembinaan terhadap klien".

Anak $S$ melakukan pencurian karena keinginan Anak $S$ untuk mendapatkan uang dengan cara mudah untuk berfoya-foya dengan teman-temannya, adanya pengaruh dan ajakan teman, adanya pergaulan serta kondisi mental klien yang mudah terpengaruh omongan temannya, Bapas Purwokerto merekomendasikan untuk dilakukan Diversi dengan pendekatan keadilan restorative untuk kepentingan terbaik bagi anak, sesuai Pasal 14 angka (2) UU RI Nomor 11 Tahun 2012 Tentang Sistem Peradilan Pidana Anak.

Setelah dilakukan musyawarah Diversi, ternyata antara korban dan Anak S tidak terjadi kesepakatan dan berdasarkan keinginan korban, maka perhadap perkara tindak pidana pencurian yang dilakukan oleh Anak $S$ dilanjutkan melalui proses hukum".

Anak $\mathrm{KH}$ melakukan pencurian karena keinginannya untuk bisa memiliki barang-barang seperti teman-temannya serta adanya pengaruh dan ajakan teman yang sering mengajak minumminuman keras sehingga Anak $\mathrm{KH}$ melakukan pencurian tersebut untuk berfoya-foya dengan teman-temannya.

Bapas Purwokerto merekomendasikan untuk dilakukan Diversi dengan pendekatan keadilan restorative untuk kepentingan terbaik bagi anak, sesuai Pasal 14 angka (2) UU RI Nomor 11 Tahun 2012 Tentang Sistem Peradilan Pidana Anak.

Setelah dilakukan musyawarah Diversi, ternyata antara korban dan Anak KH tidak terjadi kesepakatan dan berdasarkan keinginan korban, maka perhadap perkara tindak pidana pencurian yang dilakukan oleh Anak $\mathrm{KH}$ dilanjutkan melalui proses hukum.

Berdasarkan hal tersebut diatas tergambar bahwa petugas Bapas dalam membuat laporan penelitian kemasyarakatan atas perkara anak yang bernama $\mathrm{AM}, \mathrm{S}$, dan $\mathrm{KH}$ harus terlebih dahulu ada permintaan dari penyidik untuk membuat litmas terhadap perkara atas nama 
1093 | Jurnal Idea Hukum

Vol. 4 No. 2 Oktober 2018

Magister Hukum Fakultas Hukum Universitas Jenderal Soedirman

$\mathrm{AM}, \mathrm{S}$ dan $\mathrm{KH}$, dimana setelah

Bapas melakukan penelitian memberikan kesimpulan dan saran yang nantinya akan dipergunakan sebagai pertimbangan Penyidik dalam menerapkan Diversi dalam pelaksanaan Diversi perkara atas nama $\mathrm{AM}, \mathrm{S}$ dan $\mathrm{KH}$ tersebut. Penyidik dalam melakukan Diversi selain mempertimbangkan litmas dari Bapas juga harus mempertimbangkan faktorfaktor tertentu, misalkan kategori tindak pidana, atau karena umur anak masih kecil atas pertimbangan kebaikan dimasa yang akan datang pada diri korban maupun pelaku.

Pelaksanaan proses diversi terhadap perkara pencurian yang dilakukan oleh Anak sebagaimana yang dilakuak dalam perkara Anak $\mathrm{AM}, \mathrm{S}$ dan $\mathrm{KH}$ di Kepolisian Resort Banjarnegara dilakukan dengan tahap sebagai berikut:

a. Persiapan Diversi

Pertama, Penanganan
perkara yang wajib
diupayakan diversi,
Penyidik Kepolisian Resort
Banjarnegara melakukan
pemanggilan terhadap :

1) Anak dan orang tua/wali atau pendampingnya.

2) Korban dan/atau orang tua/walinya.

3) Pembimbing kemasyarakatan

4) Pekerja sosial profesional

5) Perwakilan masyarakat.

6) Pihak-pihak terkait lainnya yang dipandang perlu untuk dilibatkan dalam musyawarah diversi.

Sejak dimulainya penyidikan, Penyidik dalam jangka waktu paling lama $1 \mathrm{x}$ 24 (satu kali dua puluh empat) jam meminta:

a. Pembimbing

Kemasyarakatan untuk hadir mendampingi Anak dan melakukan penelitian kemasyarakatan; dan

b. Pekerja Sosial Profesional untuk membuat laporan sosial terhadap Anak Korban dan/atau Anak Saksi.

Selama jangka waktu paling lama $3 \times 24$ (tiga kali dua puluh empat) jam terhitung sejak tanggal diterimanya surat permintaan dari Penyidik, Pembimbing Kemasyarakatan wajib 
menyampaikan hasil penelitian kemasyarakatan dan Pekerja Sosial Profesional wajib menyampaikan hasil laporan sosial.

Selama jangka waktu paling lama 7 × 24 (tujuh kali dua puluh empat) jam terhitung sejak dimulainya penyidikan, Penyidik memberitahukan dan menawarkan kepada Anak dan/atau orang tua/Wali, serta korban atau Anak Korban dan/atau orang tua/Wali untuk menyelesaikan perkara melalui Diversi. Dalam hal Anak dan/atau orang tua/Wali, serta korban atau Anak Korban dan/atau orang tua/Wali sepakat melakukan Diversi, Penyidik menentukan tanggal dimulainya musyawarah Diversi. Dalam hal Anak dan/atau orang tua/Wali, serta korban atau Anak Korban dan/atau orang tua/Wali tidak sepakat untuk melakukan Diversi, Penyidik melanjutkan proses penyidikan, kemudian menyampaikan berkas perkara dan berita acara upaya Diversi kepada Penuntut Umum.

Proses penyelesaian perkara atas nama Tersangka AM, Penyidik Satreskrim Unit Pelayanan Perempuan dan
Anak Polres Banjarnegara sebelum dilakukannya musyawarah Diversi dilaksanakan dengan suatu persiapan yaitu memanggil berbagai pihak yaitu Anak dan orang tua/wali atau pendampingnya, Korban dan/atau orang tua/walinya, Pembimbing kemasyarakatan, Pekerja sosial professional, Perwakilan masyarakat, Pihakpihak terkait lainnya yang dipandang perlu untuk dilibatkan dalam musyawarah Diversi. Musyawarah Diversi dibuka oleh fasilitator Diversi dengan perkenalan para pihak yang hadir, menyampaikan maksud dan tujuan musyawarah Diversi, serta tata tertib musyawarah untuk disepakati oleh para pihak yang hadir agar jalannya musyawarah Diversi dapat berjalan dengan baik. Selama berlangsungnya musyawarah Diversi dicatat dalam berita acara Diversi dan ditandatangani oleh fasilitator Diversi.

b. Tahapan Musyawarah Diversi.

Musyawarah Diversi dipimpin oleh Penyidik sebagai fasilitator dan Pembimbing Kemasyarakatan sebagai 
wakil fasilitator. Musyawarah

Diversi dihadiri oleh Anak dan/atau orang tua/Wali, korban, atau Anak Korban dan/atau orang tua/Wali, dan/atau Pekerja Sosial Profesional. Musyawarah Diversi dapat melibatkan masyarakat.

Musyawarah diversi dibuka oleh fasilitator diversi dengan perkenalan para pihak yang hadir, menyampaikan maksud dan tujuan musyawarah diversi, serta tata tertib musyawarah untuk disepakati oleh para pihak yang hadir. Fasilitator diversi menjelaskan fungsi fasilitator diversi. Fasilitator diversi menjelaskan tentang ringkasan dakwaan dan pembimbing kemasyarakatan memberikan informasi tentang perilaku dan keadaan social anak serta memberikan saran untuk memperoleh penyelesaian. Fasilitator diversi memberikan kesempatan kepada :

1) Anak untuk didengar keterangan perihal dugaan tindak pidananya.

2) Orang tua/wali menyampaikan hal-hal yang berkaitan dengan perbuatan anak dan bentuk penyelesaian yang diharapkan.

3) Korban/anak korban/orang tua/wali untuk member tanggapan dan bentuk penyelesaian yang diharapkan.

Proses penyelesaian perkara tindak pidana pencurian atas nama Anak $\mathrm{AM}, \mathrm{S}$ dan $\mathrm{KH}$, oleh Penyidik Satreskrim Unit Pelayanan Perempuan dan Anak Polres Banjarnegara, dilakukan melalui musyawarah dengan pihak kepolisian sebagai pihak fasilitator dengan melibatkan Anak dan orang tua/Walinya, korban dan/atau orang tua/Walinya, Pembimbing Kemasyarakatan, dan Pekerja Sosial Profesional dimana Unit Pelayanan Perempuan dan Anak Polres Banjarnegara telah menyediakan suatu ruangan khusus untuk dilakukannya Diversi yang ramah bagi anak dimana di ruangan tersebut tidak ada simbol-simbol aparat penegak hukum dan dalam melakukan proses Diversi pihak Penyidik maupun pihak-pihak yang terkait dengan proses Diversi tidak menggunakan seragam 
kedinasan maupun simbolsimbol kedinasan dimana hal tersebut diharapkan tidak menimbulkan kesan menyeramkan dan menakutkan anak selama berjalannya proses Diversi dan selama berlangsungnya proses Diversi Anak harus dijauhkan dari adanya paksaan maupun ancaman kekerasan dan selama berlangsungnya musyawarah Diversi dicatat dalam berita acara Diversi dan ditandatangani oleh fasilitator Diversi.

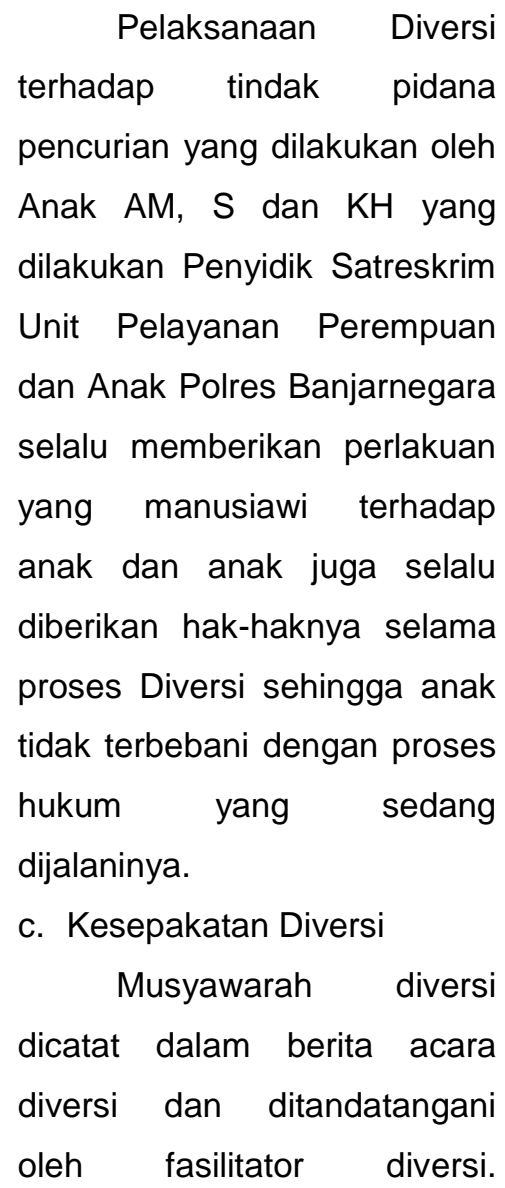

Kesepakatan diversi ditandatangani oleh para pihak dan dilaporkan kepada Ketua Pengadilan oleh fasilitator diversi. Dalam hal Diversi mencapai kesepakatan, Penyidik menyampaikan Surat Kesepakatan Diversi dan berita acara Diversi kepada atasan langsung Penyidik. Dalam jangka waktu paling lama 3 (tiga) hari terhitung sejak tanggal dicapainya kesepakatan Diversi, atasan langsung Penyidik mengirimkan Surat Kesepakatan Diversi dan berita acara Diversi kepada Ketua Pengadilan Negeri untuk memperoleh Penetapan. Penyidik meminta para pihak untuk melaksanakan kesepakatan Diversi setelah menerima penetapan. Atasan langsung Penyidik melakukan pengawasan terhadap pelaksanaan kesepakatan Diversi. Pembimbing Kemasyarakatan melakukan pendampingan,

pembimbingan, dan pengawasan pelaksanaan kesepakatan Diversi.

\begin{tabular}{lcr}
\multicolumn{2}{c}{ Proses } & penyelesaian \\
perkara & tindak & pidana \\
pencurian & atas & nama \\
Tersangka & AM, & Penyidik
\end{tabular}


1097 | Jurnal Idea Hukum

Vol. 4 No. 2 Oktober 2018

Magister Hukum Fakultas Hukum Universitas Jenderal Soedirman

Satreskrim Unit Pelayanan
Perempuan dan Anak Polres
Banjarnegara, sebagaimana
dalam perkara dengan pelaku

AM, Penyidik Polri

berkordinasi dengan Jaksa/PU dan Bapas dalam hal proses penyidikan perkara tindak pidana anak, selanjutnya penyidik mengupayakan Diversi dengan mempertimbangkan umur anak, kategori tindak pidana dan dukungan lingkungan keluarga dan masyarakat. Proses Diversi dilakukan melalui musyawarah dengan melibatkan tersangka anak, orang tua/walinya, pembimbing

kemasyarakatan/Bapas, saksisaksi dan pengacara berdasarkan pendekatan restorative justice dengan mempertimbangkan umur tersangka, korban, kesejahteraan dan tanggung jawab tersangka, menghindari stigma negative, keharmonisan masyarakat, kepatutan dan kesusilaan serta ketertiban umum. Selanjutnya dalam musyawarah Diversi sesuai tahapan musyawarah Diversi mendapatkan hasil kesepakatan Diversi dan penyidik menyampaikan hasil kesepakatan Diversi dan berita acara Diversi kepada atasan /pimpinan. Dalam waktu 3 (tiga) hari selanjutnya surat/kesepakatan Diversi dan berita acara Diversi dimaksud dikirimkan ke Ketua Pengadilan Negeri untuk mendapatkan penetapan. Setelah penyidik menerima hasil penetapan, penyidik meminta para pihak untuk melaksanakan kesepakatan Diversi tersebut.

Musyawarah Diversi terhadap pelaku tindak pidana pencurian yang dilakukan Anak AM yang masih berusia di bawah umur, Dalam musyawarah Diversi tersebut melahirkan beberapa kesepakatan kesepakatan, di antaranya pelaku dan orangtua pelaku meminta maaf kepada korban atas perbuatan yang telah dilakukannya dan pihak korban bersedia memberikan maaf dan merelakan perkara diselesaikan secara kekeluargaan. Pihak korban menganggap perkara tersebut telah selesai dan tidak akan menuntut secara hukum serta tidak akan menuntut ganti rugi kepada pelaku, pihak keluarga 
pelaku bersedia mendidik dan membina anaknya agar tidak mengulangi perbuatannya baik kepada korban maupun kepada orang lain, dan pelaku sanggup untuk dituntut secara hukum yang berlaku jika dikemudian hari mengulangi perbuatannya berjanji dan bersedia mengawasi dan menjaga, tingkah laku dan sikap anaknya di masyarakat dan tidak akan mengulangi lagi perbuatannya baik kepada korban maupun kepada orang lain. Apabila telah terjadi kesepakatan Diversi antara korban dan orang tua sebagaimana hasil kesepakatan Diveri terhadap tindak pidana pencurian yang dilakukan oleh Anak AM, Bapas Purwokerto maka pengawasan pelaksanaan hasil kesepakatan diversi diserahkan kepada orang tua, warga masyarakat dan lingkungan tersangka, penyidik, perangkat desa serta Bapas itu sendiri agar anak dapat kembali ke kehidupannya seperti sebelum terjadinya tindak pidana.

Berdasarkan uraian diatas jika dihubungkan dengan ketentuan tentang proses pelaksanaan Diversi berdasarkan Undang-Undang Nomor 11 Tahun 2012 tentang Sistem Peradilan Pidana Anak, dimana ketentuan mengenai Diversi diatur dalam BAB II Pasal 6 sampai dengan Pasal 12 yang dapat dijabarkan mengenai Diversi dimana tujuan Diversi adalah untuk mencapai perdamaian antara korban dan Anak, menyelesaikan perkara Anak di luar proses peradilan, menghindarkan Anak dari perampasan kemerdekaan, mendorong masyarakat untuk berpartisipasi; dan menanamkan rasa tanggung jawab kepada Anak.

Kesepakatan Diversi sebagaimana dimaksud padap Pasal 10 ayat (1) UndangUndang Nomor 11 Tahun 2012 tentang Sistem Peradilan Pidana Anak dilakukan oleh Penyidik atas rekomendasi Pembimbing Kemasyarakatan dapat berbentuk pengembalian kerugian dalam hal ada korban, rehabilitasi medis dan psikososial, penyerahan kembali kepada orang tua/wali, keikutsertaan dalam pendidikan atau pelatihan di lembaga pendidikan atau LPKS paling lama 3 (tiga) bulan atau 
pelayanan masyarakat paling lama 3 (tiga) bulan. Hasil kesepakatan Diversi dapat berbentuk, antara lain perdamaian dengan atau tanpa ganti kerugian, penyerahan kembali kepada orang tua/Wali, keikutsertaan dalam pendidikan atau pelatihan di lembaga pendidikan atau LPKS paling lama 3 (tiga) bulan atau pelayanan masyarakat.

Kemudian hasil

kesepakatan sebagaimana

dimaksud dalam Pasal 11

dituangkan dalam bentuk kesepakatan Diversi, dan hasil kesepakatan Diversi disampaikan oleh atasan langsung pejabat yang bertanggung jawab di setiap tingkat pemeriksaan ke pengadilan negeri sesuai dengan daerah hukumnya dalam waktu paling lama 3 (tiga) hari sejak kesepakatan dicapai untuk memperoleh penetapan. Penetapan sebagaimana dimaksud pada ayat (2) dilakukan dalam waktu paling lama 3 (tiga) hari terhitung sejak diterimanya kesepakatan Diversi, penetapan terebut disampaikan kepada Pembimbing Kemasyarakatan,
Penyidik, Penuntut Umum, atau Hakim dalam waktu paling lama 3 (tiga) hari sejak ditetapkan. Setelah menerima penetapan Penyidik menerbitkan penetapan penghentian penyidikan atau Penuntut Umum menerbitkan penetapan penghentian penuntutan.

Proses penyelesaian perkara tindak pidana pencurian atas nama Tersangka $\mathrm{S}$ dan $\mathrm{KH}$, dilakukan oleh Penyidik Satreskrim Unit Pelayanan Perempuan dan Anak Polres Banjarnegara, dengan berkordinasi dengan Jaksa/PU dan Bapas dalam hal proses penyidikan perkara tindak pidana anak, selanjutnya penyidik mengupayakan Diversi dengan mempertimbangkan umur anak, kategori tindak pidana dan dukungan lingkungan keluarga dan masyarakat. Proses Diversi dilakukan melalui musyawarah dengan melibatkan tersangka anak, orang tua/walinya, pembimbing kemasyarakatan/Bapas, saksisaksi dan pengacara berdasarkan pendekatan restorative justice dengan 
mempertimbangkan umu tersangka, korban, kesejahteraan dan tanggung jawab tersangka, menghindari stigma negative, keharmonisan masyarakat, kepatutan dan kesusilaan serta ketertiban umum. Diversi dilaksanakan setelah penyidik memperoleh rekomendasi dan atau hasil penelitian dari Bapas, selanjutnya dilakukan musyawarah Diversi sesuai tahapan musyawarah Diversi.

Musyawarah Diversi terhadap pelaku tindak pidana pencurian yang dilakukan Anak $\mathrm{S}$ yang masih berusia di bawah umur, dalam musyawarah Diversi terhadap Anak S, Penyidik Satreskrim Unit Pelayanan Perempuan dan Anak Polres Banjarnegara melakukan proses musyawarah Diversi yang dihadiri oleh Anak S dan orang tua/wali atau pendampingnya, korban, Pembimbing kemasyarakatan, Pekerja sosial professional, Perwakilan masyarakat, Pihak-pihak terkait lainnya di sebuah ruangan khusus dan selama proses musyawarah Diversi tersebut sangat terasa suasana kekeluargaan dan tidak ada tekanan atau paksaan dari penyidik Polres Banjarnegara terhadap Anak maupun korban.

Selama proses musyawarah diversi tersebut pihak Penyidik Satreskrim Unit Pelayanan Perempuan dan Anak Polres Banjarnegara berusaha mencari jalan yang terbaik agar diversi tersebut bisa berhasil, namun korban menginginkan agar proses hukum terhadap Anak $S$ tetap dilanjutkan dikarenakan $S$ sudah pernah melakukan pencurian disekitar tempat tinggal korban namun saat itu sudah diselesaikan secara kekeluargaan dan Anak S berjanji tidak akan melakukan perbuatannya lagi, namun kenyataannya Anak S kembali melakukan pencurian sehingga korban menginginkan proses hukum terhadap Anak $S$ tetap dilanjutkan sekaligus memberi efek jera kepada Anak $S$ agar tidak melakukan pencurian lagi.

Selama pelaksanaan musyawarah Diversi tersebut tidak ada paksaan ataupun ancaman baik kepada korban maupun kepada Anak S, suasananya penuh rasa kekeluargaan dan pihak 
1101 | Jurnal Idea Hukum

Vol. 4 No. 2 Oktober 2018

Magister Hukum Fakultas Hukum Universitas Jenderal Soedirman

\begin{tabular}{lr} 
kepolisian memberikan & \multicolumn{1}{r}{ masilitas } \\
penjelasan maun & fana \\
yang memadai & selama \\
berjalannya & proses \\
musyawarah Diversi. &
\end{tabular}

Musyawarah Diversi terhadap pelaku tindak pidana pencurian yang dilakukan Anak $\mathrm{KH}$ yang masih berusia di bawah umur, dalam musyawarah Diversi terhadap Anak KH, Penyidik Satreskrim Unit Pelayanan Perempuan dan Anak Polres Banjarnegara melakukan proses musyawarah Diversi yang dihadiri oleh Anak $\mathrm{KH}$ dan orang tua/wali atau pendampingnya, korban, Pembimbing kemasyarakatan, Pekerja sosial professional, Perwakilan masyarakat, Pihakpihak terkait lainnya di sebuah ruangan khusus dan selama proses musyawarah Diversi tersebut sangat terasa suasana kekeluargaan dan tidak ada tekanan atau paksaan dari penyidik Polres Banjarnegara terhadap Anak maupun korban.

Selama proses musyawarah diversi tersebut pihak Penyidik Satreskrim Unit Pelayanan Perempuan dan Anak Polres Banjarnegara berusaha mencari jalan yang terbaik agar diversi tersebut bisa berhasil, namun dalam pelaksanaan musyawarah Diversi tersebut tidak menghasilkan kesepakatan Diversi, dikarenakan korban menginginkan agar proses hukum terhadap Anak $\mathrm{KH}$ tetap dilanjutkan melalui jalur persidangan karena korban ingin memberikan efek jera kepada Anak $\mathrm{KH}$ yang telah melakukan pencurian di rumah korban dan perbuatan Anak $\mathrm{KH}$ ini merupakan kejadian yang kedua kalinya dimana perbuatan Anak $\mathrm{KH}$ sebelumnya diselesaikan secara kekeluargaan, namun ternyata Anak $\mathrm{KH}$ kembali melakukan perbuatannya lagi sehingga korban merasa jengkel dan menginginkan proses hukum terus berjalan sekaligus untuk memberikan efek jera kepada Anak $\mathrm{KH}$ agar tidak melakukan perbuatannya lagi. Selain itu perbuatan Anak $\mathrm{KH}$ juga membuat resah warga di sekitar tempat tinggal korban.

Terhadap pelaksanaan

\begin{tabular}{|c|c|}
\hline $\begin{array}{l}\text { musyawarah } \\
\text { tidak }\end{array}$ & $\begin{array}{l}\text { Diversi yang } \\
\text { menghasilkan }\end{array}$ \\
\hline kesepakatan & Diver \\
\hline sebagaimana & dalam \\
\hline usyawarah & Diversi \\
\hline
\end{tabular}




\begin{abstract}
pidana pencurian yang dilakukan oleh Anak $S$ dan $\mathrm{KH}$, penyidik melanjutkan penyidikan dan melimpahkan perkara ke Penuntut Umum dengan melampirkan berita acara diversi dan laporan penelitian kemasyarakatan.
\end{abstract}

Terhadap pelaksanaan musyawarah Diversi yang tidak menghasilkan kesepakatan Diversi disebutkan dalam Pasal 29 Ayat (4) Undang-Undang Nomor 11 tahun 2012 tentang Sitem Peradilan Pidana Anak yang menyebutkan bahwa dalam hal Diversi gagal, penyidik wajib melanjutkan penyidikan dan melimpahkan perkara ke Penuntut Umum dengan melampirkan berita acara diversi dan laporan penelitian kemasyarakatan.

Berdasarkan uraian tersebut diatas, maka dapat diperoleh gambaran bahwa pelaksanaan Diversi bagi anak yang melakukan tindak pidana pencurian di wilayah hukum Polres Banjarnegara yang dilakukan oleh Penyidik Satreskrim Unit Pelayanan Perempuan dan Anak Polres Banjarnegara telah sesuai dengan ketentuan Pasal 7 ayat (2) Undang-Undang
Nomor 11 Tahun 2012 Tentang Sistem Peradilan Pidana Anak, namun pada kenyataannya pelaksanaan Diversi bagi anak yang melakukan tindak pidana pencurian yang dilakukan oleh Anak belum memberikan hasil yang efektif terhadap penanganan tindak pidana pencurian yang dilakukan oleh Anak, dimana dari 3 perkara tindak pidana pencurian yang dilakukan oleh Anak yang dilakukan proses Diversi, ternyata hanya 1 perkara yang dapat menghasilkan kesepakatan Diversi, sedangkan 2 perkara lainnya tidak berhasil mencapai kesepakatan dan dilanjutkan melalui proses persidangan.

2. Hambatan-Hambatan Dalam Pelaksanaan Diversi Terhadap Tindak Pidana Pencurian Yang Dilakukan Oleh Oleh Penyidik Satreskrim Unit Pelayanan Perempuan dan Anak Polres Banjarnegara.

Faktor faktor pelaksanaan diversi bagi anak yang melakukan tindak pidana di wilayah hukum Polres Banjarnegara adalah sebagai berikut :

a. Faktor Penegak Hukum 
1103 | Jurnal Idea Hukum

Vol. 4 No. 2 Oktober 2018

Magister Hukum Fakultas Hukum Universitas Jenderal Soedirman

\begin{abstract}
Ruang lingkup suatu penegakan hukum adalah sangat luas, karena mencakup mereka yang secara langsung maupun tidak langsung berkecimpung dalam penegakan hukum. ${ }^{92}$ Untuk membatasi hal yang luas tersebut maka mengartikan penegakan hukum skala subjektif penegakan hukum haruslah tertentu yaitu polisi, jaksa, hakim, dan pengacara.

Kurangnya pemahaman aparat penegak hukum (kepolisian) tentang makna dan tujuan diversi, kurangnya pelatihan-pelatihan terhadap aparat penegak hukum (kepolisian) serta rendahnya kesadaran penegak hukum untuk menerapkan diversi menjadikan anak pelaku tindak pidana diproses hingga ke Pengadilan, sehingga berakhir di penjara. Faktor penegak hukum memegang peran dominan. Beberapa permasalahan yang dihadapi penegak hukum antara lain:
\end{abstract}

1) Tingkat aspirasi yang belum tinggi

2) Kegairahan yang sangat terbatas untuk memikirkan masa

92 Soerjono Soekanto, 2011, FaktorFaktor Yang Mempengaruhi Penegakan Hukum, PT.Raja Grafindo Persada, Jakarta hal 8 . depan, sehingga sulit sekali untuk membuat suatu proyeksi.

3) Belum adanya kemampuan menunda pemuasan suatu kebutuhan tertentu, terutama kebutuhan materil.

4) Kurangnya daya inovatif yang sebenarnya merupakan pasangan konservatisme.

5) Keterbatasan

kemampuan untuk menempatkan diri dalam peranan pihak lain dengan siapa dia berinteraksi. $^{93}$

b. Faktor Sarana atau

Fasilitas

Walaupun keadilan Restoratif Justice dan Diversi sudah mulai dikenal sebagai alternatif penanganan anak berhadapan dengan hukum dari peradilan pidana dan mulai mendapatkan dukungan banyak pihak masih banyak hambatan yang dihadapi oleh sistem peradilan anak. Terbatasnya sarana dan prasarana penanganan anak berhadapan dengan hukum selama proses pengadilan (pra dan pasca putusan pengadilan).

Tanpa adanya fasilitas tertentu, maka tidak mungkin penegakan hukum akan berlangsung dengan lancar.

${ }^{93}$ Ibid., hal.34-35 
Sarana atau fasilitas tersebut antara lain mencakup tenaga manusia yang berpendidikan dan terampil, organisasi yang baik, peralatan yang memadai, keuangan yang cukup dan lainnya. ${ }^{94} \quad$ Penyidik/penyidik pembantu dalam melaksanakan tugasnya seharusnya dilengkapi berbagai sarana dan fasilitas berupa penyediaan fasilitasfasilitas untuk mendukung pelaksanaan tugasnya.

c. Faktor Masyarakat Penegakan hukum berasal dari masyarakat dan bertujuan untuk mencapai kedamaian di dalam masyarakat. Oleh karena itu dipandang dari sudut tertentu, maka masyarakat dapat mempengaruhi penegakan hukum tersebut. Terdapat beberapa faktor masyarakat yang menimbulkan hambatan bagi penegakan hukum anatara lain :

1) Tidak mengetahui atau tidak menyadari, apabila hak-hak mereka dilanggar atau terganggu,

2) Tidak mengetahui akan adanya upaya-upaya hukum untuk melindungi kepentingan-

kepentingannya,

3) Tidak berdaya untuk memanfaatkan upayaupaya hukum karena faktor-faktor keuangan, psikis, sosial atau politik,

4) Tidak mempunyai pengalaman menjadi anggota organisasi yang memperjuangkan kepentingankepentingannya,

5) Mempunyai pengalamanpengalaman kurang baik di dalam proses interaksi dengan pelbagai unsur kalangan hukum formal. ${ }^{95}$

Ketentuan dalam Peraturan Pemerintah Republik Indonesia Nomor 65 Tahun $2015 \quad$ Tentang Pedoman Pelaksanaan Diversi dan Penanganan Anak Yang Belum Berusia 12 (dua belas) tahun dikeluarkan oleh Pemerintah sesuai amanat dari Pasal 15 Undang-Undang Nomor 11 Tahun 2012 Tentang Sistem Peradilan Pidana Anak yang mengatur tentang Ketentuan mengenai 
1105 | Jurnal Idea Hukum

Vol. 4 No. 2 Oktober 2018

Magister Hukum Fakultas Hukum Universitas Jenderal Soedirman

pedoman pelaksanaan proses

Diversi, tata cara dan

koordinasi pelaksanaan

Diversi diatur dengan

Peraturan Pemerintah.

Melihat ketentuan diatas

tergambar bahwa faktor-faktor

yang menghambat

dilaksanakan Diversi pada

waktu itu karena belum

adanya peraturan

pelaksanaan dari Undang-

Undang Nomor 11 tahun 2012

tentang Sistem Peradilan

Pidana Anak terutama

mengenai Diversi. Faktor

penghambat ini dapat

dimasukkan dalam faktor

subsatansi hukum. Sedangkan

faktor-faktor penghambat

lainnya dimasukkan dalam

faktor budaya ketika

mengumpulkan para pihak,

lamanya waktu untuk sepakat

dan adanya kecurigaan dari

sebagian warga mengenai

diversi sehingga perlu adanya

sosialisasi kepada masyarakat

mengenai adanya diversi

dalam penyelesaian perkara

anak yang berhadapan

dengan hukum dalam Undang-

Undang Nomor 11 Tahun

2012 Tentang Sistem

Peradilan Pidana Anak,

sehingga efektifitas hukum sebagaimana diharapkan

belum tercapai.

Hal ini sesuai dengan pendapat dari Nurnaningsih Amriani yang dimuat dalam Varia peradilan yang mengatakan bahwa hal-hal yang menghambat pelaksanaan Diversi sebagai berikut : ${ }^{96}$

a. Belum ada undangundang yang secara tegas mengatur mengenai konsep Diversi dan restorative justice.

b. Adanya rasa khawatir bahwa pelaksanaan Diversi justru menimbulkan pelanggaran terhadap HAM.

C. Aspek tindak pidana yang dilakukan oleh anak dibawah umur 18 tahun (anak) akan menjadi sangat dilematis karena disatu sisi aparat penegak hukum, dalam hal ini polisi harus menegakkan hukum dan disisi lain harus melindungi anak.

\footnotetext{
${ }^{96}$ Nurnaningsih Amriani, 2012,
} Penanganan Perkara Anak Melalui Konsep Diversi Dan Restorative Justice, Varia Peradilan, artikel, Ikahi, Jakarta 
d. Belum ada kesepahaman anara aparat penegak hukum manupun dengan masyarakat.

e. Tingkat keseriusan dalam menangani kasus yang menyangkut anak masih belum merata.

f. Lembaga pengasuh anak ada yang legal dan ada yang sebagai kedok yang dikhawatirkan menimbulkan perdagangan anak.

g. Masih banyak orang tua yang bersifat emosional yang puas dengan proses balas dendam melalui penjara sehingga kurang mendukung fungsi pembinaan terhadap anak.

h. Sarana dan prasarana yang belum memadai sehingga tidak dapat menfasilitasi

perlindungan anak (ruang tahanan anak, ruang bermain, jaminan kesehatan, fasilitas belajar dan biaya operasional dan sebagainya).
Sehubungan dengan pendapat Nurnaningsih Amriani tersebut apabila dihubungkan dengan faktorfaktor yang menghambat dalam pelaksanaan diversi oleh penyidik anak dalam penyelesaian tindak pidana pencurian yang dilakukan oleh anak di Wilayah Hukum Polres Banjarnegara dapat dimasukkan dalam point a dan point $b$ yaitu belum ada undang-undang yang secara tegas mengatur mengenai konsep Diversi dan restorative justice dan adanya rasa khawatir bahwa pelaksanaan Diversi justru menimbulkan pelanggaran terhadap Hak Asasi Manusia.

Pandangan atau anggapan bahwa hukum adalah hukum positif tertulis belaka adalah adanya kecenderungan yang kuat sekali bahwa satu-satunya tugas hukum adalah adanya kepastian hukum. Dengan adanya kecenderungan untuk lebih menekankan pada kepastian hukum belaka, maka akan muncul anggapan yang kuat sekali bahwa satusatunya tujuan hukum adalah ketertiban.

Lebih mementingkan ketertiban 
1107 | Jurnal Idea Hukum

Vol. 4 No. 2 Oktober 2018

Magister Hukum Fakultas Hukum Universitas Jenderal Soedirman

berarti lebih menekankan pada

kepentingan umum, sehingga

timbul gagasan-gagasan yang

kuat bahwa semua bidang

kehidupan akan dapat diatur

dengan hukum tertulis.

Kecenderungan-

kecenderungan yang legistis

tersebut pada akhimya akan

menemukan kepuasan pada

lahirnya perundang-undangan

yang belum tentu berlaku

secara sosiologis. ${ }^{97}$

\section{E. PENUTUP}

\section{Simpulan}

Berdasarkan dari hasil penelitian tersebut di atas dapat diambil suatu simpulan sebagai berikut :

1. Pelaksanaan Diversi bagi anak yang melakukan tindak pidana pencurian di wilayah hukum Polres Banjarnegara yang dilakukan oleh Penyidik Satreskrim Unit Pelayanan Perempuan dan Anak Polres Banjarnegara telah sesuai dengan ketentuan Pasal 7 ayat (2) Undang-Undang Nomor 11 Tahun 2012 Tentang Sistem Peradilan Pidana Anak yang dilakukan dengan beberapa tahap yaitu :

a. Tahap persiapan diversi.

97 Soerjono Soekanto, 2011, Faktor-Faktor yang mempengaruhi Penegakan Hukum, PT. Raja Grafindo Perkasa, Jakarta., hal. 57.
Tahap Persiapan proses

diversi dilakukan dengan pemanggilan oleh Penyidik Satreskrim Unit Pelayanan Perempuan dan Anak Polres Banjarnegara kepada para pihak yang berkepentingan dan pihak yang diatur oleh Undang Undang No.11 Tahun 2012 Tentang Sistem Peradilan Pidana Anak untuk melakukan proses Diversi di suatu ruangan khusus untuk dilakukannya Diversi yang telah disediakan oleh Unit Pelayanan Perempuan dan Anak Polres Banjarnegara. Persiapan Diversi dilakukan oleh Penyidik Satreskrim Unit Pelayanan Perempuan dan Anak Polres Banjarnegara dengan melakukan pemanggilan berbagai pihak yaitu Anak dan orang tua/wali atau pendampingnya, Korban dan/atau orang tua/walinya, Pembimbing

kemasyarakatan, Pekerja sosial professional, Perwakilan masyarakat, Pihak-pihak terkait lainnya yang dipandang perlu untuk dilibatkan dalam musyawarah diversi.

b. Tahap musyawarah. 


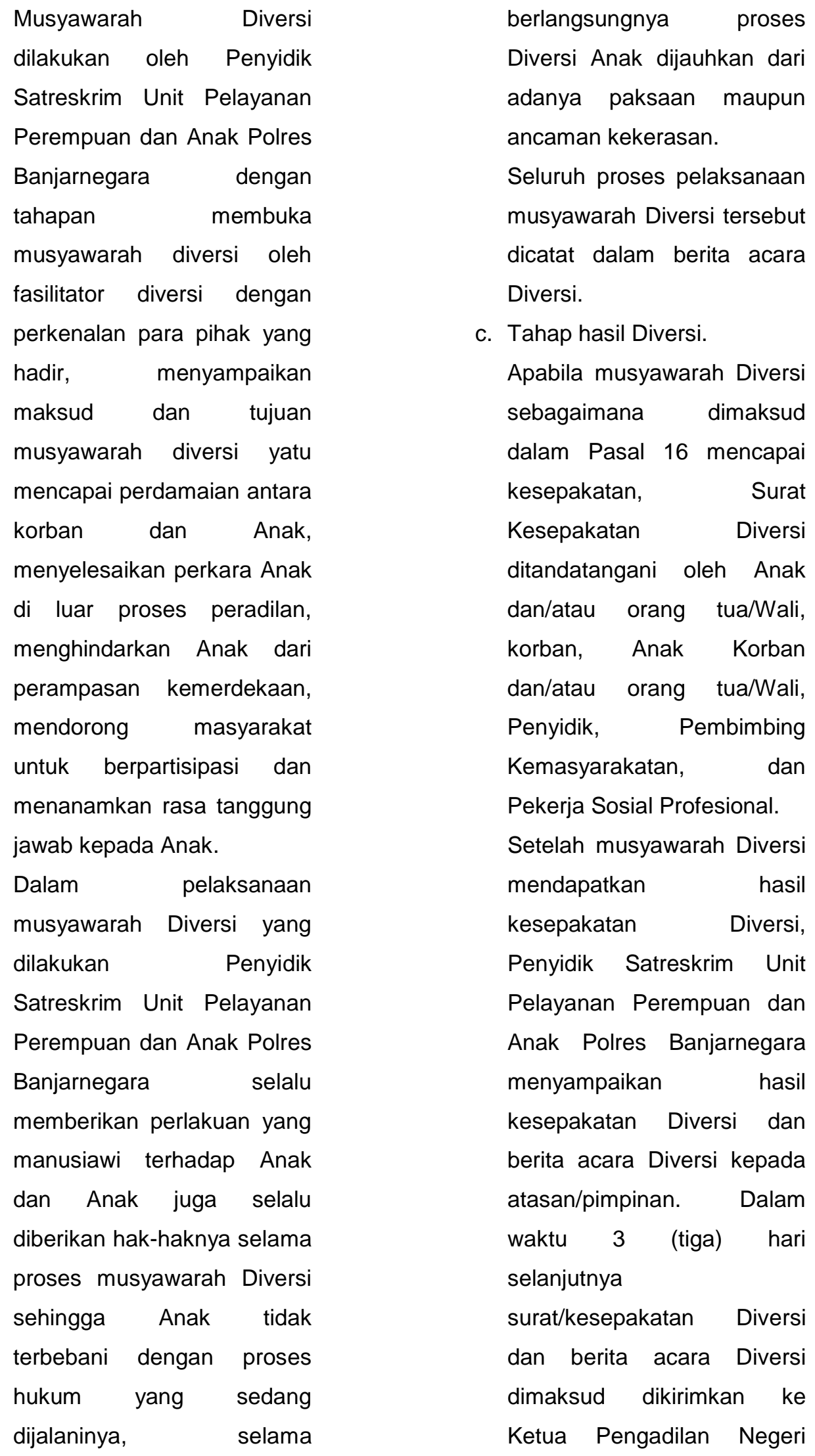




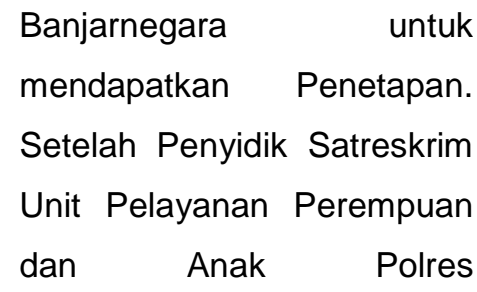

Banjarnegara menerima hasil Penetapan, penyidik meminta para pihak untuk melaksanakan kesepakatan Diversi tersebut dan setelah para pihak melaksanakan kesepakatan Diversi, Penyidik menerbitkan surat ketetapan penghentian penyidikan yang disampaikan kepada Penuntut beserta laporan proses Diversi dan berita acara pemeriksaan dengan tembusan kepada Anak dan orang tua/Wali, korban, Pembimbing

Kemasyarakatan, Pekerja

Sosial Profesional, dan

Ketua Pengadilan Negeri setempat.

Meskipun pelaksanaan Diversi bagi anak yang melakukan tindak pidana pencurian di wilayah hukum Polres Banjarnegara yang dilakukan oleh Penyidik Satreskrim Unit Pelayanan Perempuan dan Anak Polres Banjarnegara telah sesuai dengan ketentuan Pasal 7 ayat (2) Undang-Undang Nomor 11 Tahun 2012 Tentang
Sistem Peradilan Pidana Anak, namun pada kenyataannya pelaksanaan Diversi bagi anak yang melakukan tindak pidana pencurian yang dilakukan oleh Anak belum memberikan hasil yang efektif, dimana dari 3 perkara tindak pidana pencurian yang dilakukan oleh Anak yang dilakukan proses Diversi, ternyata hanya 1 perkara yang dapat menghasilkan kesepakatan Diversi, sedangkan 2 perkara lainnya tidak berhasil mencapai kesepakatan dan dilanjutkan melalui proses persidangan, sehingga tujuan dari Diversi yaitu mencapai perdamaian antara korban dan Anak, menyelesaikan perkara Anak di luar proses peradilan dan menghindarkan Anak dari perampasan kemerdekaan masih belum tercapai.

2. Hambatan-Hambatan Dalam Pelaksanaan Diversi Tindak Pidana Pencurian Yang Dilakukan Oleh Anak Yang Dialami Oleh Penyidik Satreskrim Unit Pelayanan Perempuan dan Anak Polres Banjarnegara ada beberapa faktor yaitu:

a. Faktor Subtansi Hukum yaitu belum adanya Peraturan pelaksanaan dari Undang-Undang Nomor 11 
tahun 2012 tentang Sistem Peradilan Pidana Anak terutama mengenai Diversi, belum adanya SOP bagi kepolisian mengenai diversi bagi perkara sebagaimana amanat dari UndangUndang Nomor 11 Tahun 2012 Tentang Sistem Peradilan Pidana Anak

b. Faktor budaya hukum yaitu masih kurangnya pemahaman masyarakat tentang arti pentingnya Diversi serta masih adanya kecurigaan dari sebagian warga masyarakat terhadap pelaksanaan Diversi.

\section{Saran}

1. Perlu adanya SOP bagi kepolisian mengenai pelaksanaan proses Diversi sebagaimana diamanatkan oleh Undang-Undang Nomor 11 Tahun 2012 Tentang Sistem Peradilan Pidana Anak.

2. Perlu adanya Sosialisasi mengenai Undang-Undang Nomor 11 Tahun 2012 Tentang Sistem Peradilan Pidana Anak termasuk didalamnya mengenai upaya Diversi terhadap penanganan tindak pidana yang dilakukan oleh anak.
Gultom, Maidin, 2008, Perlindungan Hukum Terhadap Anak dalam Sistem Peradilan Pidana Anak di Indonesia, Refika Aditama, Bandung.

Marlina, 2008, Penerapan Konsep Diversi Terhadap Anak Pelaku Tindak Pidana dalam Sistem Peradilan Pidana Anak, Jurnal Equality, Jakarta.

Soekanto, Soerdjono, 2011, FaktorFaktor yang mempengaruhi Penegakan Hukum, PT. Raja Grafindo Perkasa, Jakarta.

Subakti, Natangsa, 2015, Peradilan Restoratif Dalam Bingkai Empiri, Teori dan Kebijakan, Genta Publising, Yogyakarta.

Sudarto, 2006, Kapita Selekta Hukum Pidana, Cetakan ke-3, PT Alumni, Bandung.

Wahyudi, Setya, 2011, Implementasi Ide Diversi Dalam Pembaruan Sistem Pidana Anak Di Indonesia, Genta Publishing, Yogyakarta.

Amriani, Nurnaningsih, 2012, Penanganan Perkara Anak Melalui Konsep Diversi Dan Restorative Justice, Varia Peradilan, artikel, Ikahi, Jakarta.

\section{DAFTAR PUSTAKA}

